\title{
KEABSAHAN PERJANJIAN KERJA WAKTU TERTENTU DENGAN KONSEP REMOTE WORKING DALAM PRESPEKTIF UNDANG-UNDANG CIPTA KERJA
}

\author{
Isdian Anggraeny \\ Fakultas Hukum, Universitas Muhammadiyah Malang, \\ Jalan Raya Tlogomas Nomor 246 Malang, \\ Email : isdian@umm.ac.id \\ Nur Putri Hidayah \\ Fakultas Hukum, Universitas Muhammadiyah Malang, \\ Jalan Raya Tlogomas Nomor 246 Malang, \\ Email : nurputri@umm.ac.id
}

\begin{abstract}
Abstrak
Era industri 4.0 mendukung perkembangan sistem bekerja secara Remote Working. Dengan berbagai sistem yang ada, hubungan kerja yang timbul antara Pemberi kerja dan Pekerja dimulai dengan adanya Perjanjian Kerja. Secara fakta, Perjanjian kerja yang seringkali memgalami permasalahan di Indonesia adalah PKWT. Remote working dalam PKWT yang dilakukan melalui media elektronik tentunya harus dilihat dari berbagai aspek hukum, yaitu: KUHPerdata, UU Ketenagakerjaan dan UU Cipta Kerja sebagai pembaharuannya, serta UU ITE. Oleh karena itu, penulisan ini akan menguraikan beberapa hal yaitu: Pertama, bagaimana pola PKWTdengan konsep Remote Working dalam prespektif UU Cipta Kerja?; Kedua, bagaimana keabsahan PKWTdengan konsep remote working dalam prespektif UU Cipta Kerja?. Dengan menggunakan metode penelitian yuridis normatif dapat diuraikan bahwa PKWT dengan konsep remote working pada prinsipnya jg harus tunduk pada UU Ketenagakerjaan dan UU Cipta Kerja. Selain itu, terdapat beberapa aspek hukum yang harus diperhatikan oleh para pihak dalam perjanjian kerja sehingga keabsahan perjanjian kerja dapat terpenuhi dan dapat melindungi hak dan kewajiban masing-masing pihak.
\end{abstract}

Kata kunci: Keabsahan, Perjanjian Kerja Waktu Tertentu, Remote Working, UU Cipta Kerja.

\section{Abstract}

The industrial era 4.0 supports the development of a working system remote. With various existing systems, the working relationship that arises between an employer and an employee begins with a work agreement. The work agreement that often has problems in Indonesia is 
PKWT. Remote working in PKWT which is carried out through electronic media must of course be seen from various legal aspects, namely: the Civil Code, the Manpower Law and the Job Creation Law as a renewal, and the ITE Law. Therefore, this paper will describe several things, namely: First, how is the PKWT pattern with the concept of Remote Working in the perspective of the Job Creation Law?; Second, what is the validity of PKWT with the concept of creation remote working in the perspective of the Job Law? By using the normative juridical research method, it can be explained that PKWT with the remote working concept in principle must also comply with the Manpower Law and the Job Creation Law. Besides, several legal aspects must be considered by the parties in the work agreement so that the validity of the work agreement can be fulfilled and can protect the rights and obligations of each party.

Keywords: Legality, Fixed Term Work Agreement, Remote Working, Job Creation Law.

\section{PENDAHULUAN}

\section{A. Latar Belakang}

Revolusi Industri 4.0. menuntut setiap sektor memanfaatkan teknologi informasi dan komunikasi. ${ }^{1}$ Revolusi Industri 4.0 memberikan dampak terhadap perkembangan pasar global semakin dinamis. Selain itu, Revolusi Industri 4.0 merupakan penyebab munculnya konsep industrial internet of thing. ${ }^{2}$ Industrial internet of things merupakan perangkat pada jaringan internet yang dapat dikenakan untuk berkomunikasi dengan orang lain tanpa menghiraukan dekat atau jauhnya jarak komunikasi. ${ }^{3}$ Hal ini tentu pada akhirnya melahirkan pelaksanaan produksi berbasis internet sehingga dapat memberikan kemudahan bagi masyarakat global. Hal ini sebagaimana disampaikan oleh Menteri Perindustrian Indonesia bahwa Revolusi Industri

\footnotetext{
${ }^{1}$ Kementerian Perindustrian Indonesia, "Making Indonesia 4.0: Strategi RI Masuki Revolusi Industri Ke-4," www.kemenperin.go.id, 2018, https://www.kemenperin.go.id/artikel/18967/Making-Indonesia-4.0:-Strategi-RIMasuki-Revolusi-Industri-Ke-4.

${ }^{2}$ Hoedi Prasetyo and Wahyudi Sutopo, "Industri 4.0: Telaah Klasifikasi Aspek Dan Arah Perkembangan Riset," Jurnal Teknik Industri 13, no. 1 (2018): 17-26.

3 Matt Burgess, "What Is the Internet of Things? WIRED Explains," WIRED Explains, 2018, https://www.wired.co.uk/article/internet-of-things-whatis-explained-iot.
} 
4.0 merupakan salah satu usaha untuk melakukan perubahan di dunia industri yang memanfaatkan perkembangan dunia online. ${ }^{4}$

Revolusi Industri 4.0 ini juga merupakan awal dari berkembangnya konsep kerja jarak jauh atau disebut dengan remote working. ${ }^{5}$ Remote working adalah bekerja dengan kontrol kerja jarak jauh yang pelaksanaan pekerjaannya dapat dilakukan dimana saja. ${ }^{6}$ Konsep kerja remote working lahir bukan hanya karena didukung berkembangnya teknologi informasi, namun juga karena karakter kepemimpinan, pandangan, hingga perspektif tentang dunia kerja yang berbeda-beda. ${ }^{7}$ Karakter, pandangan dan perspektif kerja ini dipengaruhi erat perihal era kelahiran yang kemudian diklasifikasikan dalam konsep Multigeneration work place. $^{8}$

Remote working saat ini semakin popular di Indonesia, bahkan Kementerian Perencanaan Pembangunan Nasional akan menerapkan konsep ini untuk diterapkan pada Pegawai Negeri Sipilnya. ${ }^{9}$ Terdapat beberapa pandangan bahwa remote working memiliki banyak kelebihan yang dapat diperoleh Pengusaha maupun Pekerja. Berdasarkan penilitian dari Nicholas Bloom, Remote Working memiliki dampak positif pada diri karyawan karena penerapan Remote Working memiliki kepuasan tinggi terhadap pekerjaannya. ${ }^{10}$ Selain itu, Pekerja dapat lebih fokus terhadap pekerjannya, kehidupan keluarga yang lebih baik, dan meghemat biaya tranportasi perjalanan ke kantor. ${ }^{11}$ Dari sisi pengusaha, dampak positif yang didapatkan

\begin{tabular}{cccc}
\hline & ${ }^{4}$ Kementerian Perindustrian Indonesia, "Industry 4.0 Tingkatkan Produktivitas, \\
Tenaga & Kerja, & Dan
\end{tabular} https://www.kemenperin.go.id/artikel/17503/Industry-4.0-Tingkatkan-Produktivitas,-

Tenaga-Kerja,-dan-Pasar.

5 Kimberly A. Eddleston and Jay Mulki, "Toward Understanding Remote Workers' Management of Work-Family Boundaries: The Complexity of Workplace Embeddedness," Group \& Organization Management 42, no. 3 (June 2017): 346-87, https://doi.org/10.1177/1059601115619548.

${ }^{6}$ Irene Hardill and Anne Green, "Remote Working - Altering the Spatial Contours of Work and Home in the New Economy," New Technology, Work and Employment 18, no. 3 (November 2003): 212-22, https://doi.org/10.1111/1468-005X.00122.

7 Sriti Mayang Sari, "Implementasi Konsep Geo-Office," Pengaruh Teknologi Informasi Pada Impelentasi Konsep Geo-Office, 2006, 25-30.

${ }^{8}$ Sari.

9 CNBC Indonesia, "Cerita PNS Yang Mulai 2020 Bisa Ngantor Dari Rumah," www.cnbcindonesia.com, 2019, https://www.cnbcindonesia.com/news/20191124130238-4117540/cerita-pns-yang-mulai-2020-bisa-ngantor-dari-rumah.

10 Nicholas Bloom et al., "DOES WORKING FROM HOME WORK? EVIDENCE FROM A CHINESE EXPERIMENT,” 2013, file://D:/jurnal/jurnal 2020/ICLIS/BAHAN/w18871.pdf\%250D.

11 Zara Greenbaum, "The Future of Remote Work," American Psycological Associatio, 2019. 
yaitu Pengusaha dapat merekrut tenaga kerja yang dari berbagai daerah, tidak perlu mempersiapkan ruang kerja di kantor, dan tentunya terdapat penghematan terhadap tunjangan transportasi.

Remote Working tentu saja juga menimbulkan suatu hubungan hukum antara Pengusaha dan Pekerja karena perikatan yang muncul diantara mereka disebabkan adanya suatu kesepakatan berupa kontrak/perjanjian kerja. Dengan adanya perjanjian, timbulah hubungan hukum yang menimbulkan hak dan kewajiban pada masing-masing pihak. ${ }^{12}$ Hubungan hukum dalam hal ini oleh Pasal 1 Angka 15 Undang-Undang Ketenagakerjaan disebut dengan Hubungan Kerja yang pada dasarnya memiliki unsur pekerjaan, upah, dan perintah ${ }^{13}$. Hubungan kerja antara pengusaha dan pekerja harus dibuat dengan perjanjian kerja, baik melalui Perjanjian Kerja Waktu Tertentu (selanjutnya disebut PKWT) maupun Perjanjian Kerja Waktu Tidak Tertentu (selanjutnya disebut PKWT). ${ }^{14}$

PKWT seringkali menimbulkan permasalahan pada prakteknya. PKWT atau pada umumnya dikenal dengan sistem kerja kontrak seringkali mendominasi dari beberapa kasus ketenagakerjaan yang ditangani pihak Dinas Tenaga Kerja dan Transmigrasi. ${ }^{15}$ Tentunya hal ini menjadi salah satu perhatian Penulis untuk mengambil salah satu contoh PKWT dengan konsep remote working yang dalam prakteknya dilakukan melalui transaksi elektronik. PKWT tersebut terjadi di antara perusahaan A dan Pekerja B. Perusahaan A merupakan perusahaan yang bergerak di bidang penyelenggaraan kegiatan transfer dana lintas negara dengan perusahaan induk di Singapura dan memiliki cabang di Jakarta, Indonesia. Perusahaan A yang berkedudukan di Indonesia melakukan perekrutan dengan Pekerja B untuk menjalankan kegiatan operasional perusahaan di bidang Back-end Developer. Hubungan kerja terjadi dengan adanya PKWT sejak tanggal 1 Agustus 2019. Hingga saat ini Pekerja B masih berstatus sebagai Pekerja di Perusahaan A.

12 Totok Dwinur Haryanto, "Hubungan Hukum Yang Menimbulkan Hak Dan Kewajiban Dalam Kontrak Bisnis," Wacana Hukum IX (2010): 85-97, http://ejurnal.unisri.ac.id/index.php/Wacana/article/view/306/268.

13 Republik Indonesia, "Undang-Undang Nomor 13 Tahun 2013 Tentang Ketenagakerjaan" (2013).

14 Yuliana Yuli, Sulastri, and Dwi Aryanti, "Implementasi Undang-Undang Ketenagakerjaan Dalam Perjanjian Kerja Antara Perusahaan Dan Tenagakerja Di Perseroan Terbatas," Jurnal Yuridis 5, no. 2 (2018): 186-209, https://doi.org/10.1111/an.1994.35.9.30.3.

15 Kabar Banten, "Masalah Ketenagakerjaan Selama 2019, Kasus PKWT Mendominasi," www.kabar-banten.com, 2020, https://www.kabar-banten.com/masalahketenagakerjaan-selama-2019-kasus-pkwt-mendominasi/. 
PKWT yang telah ditandatangani oleh Pekerja B yang dibuat pada tahun 2019 dan tunduk pada UU Ketenagakerjaan terindentifikasi ada penyimpangan dari ketentuan perundang-undangan, seperti adanya masa percobaan, tempat, dan tanggal perjanjian kerja dibuat. Namun, dengan disahkan UU Cipta Kerja pada tahun $2020^{16}$, ketentuan ketenagakerjaan tidak lagi berpayung hukum hanya berdasarkan UU Ketenegakerjaan. Beberapa pasal dalam UU Ketenagakerjaan mengalami perubahan, baik pasal dirubah maupun dihapus oleh UU Cipta Kerja. Salah satu ketentuan yang dirubah oleh UU Cipta kerja adalah ketentuan terkait PKWT. Oleh karena itu, menurut Penulis, PKWT dengan konsep Remote Working antara Perusahaan A dan Pekerja B ini dapat tetap dikaji keabsahannya dalam prespektif UU Cipta Kerja dengan tetap membandingkan beberapa ketentuan UU Ketenagakerjaan yang telah dirubah sehingga tampak jelas perubahannya dan dapat dijadikan pedoman PKWT dengan konsep Remote Working di kemudian hari. Selain aspek hukum ketenagakerjaan, PKWT dengan konsep Remote working juga tidak lepas juga dengan aspek hukum lainnya yaitu Kitab Undang-Undang Hukum Perdata dan UU Informasi dan Transaksi Elektronik karena pelaksanaan pembuatan perjanjiannya dibuat secara elektronik ${ }^{17}$.

Berkaitan dengan gagasan penelitian ini telah diketahui bahwa penelitian terdahulu membahas perihal sebagai berikut: implementasi perjanjian kerja di suatu perseoran terbatas ${ }^{18}$, analisis PKWTT $^{19,20}$, analisis hubungan hukum antara pengusaha dan pekerja freelancer yang tidak terikat dengan hubungan kerja namun terikat pada hubungan hukum yang berdasarkan perjanjian jasa ${ }^{21}$, penilaian terhadap pertumbuhan kerja jarak jauh dan konsekuensinya untuk upaya, kesejahteraan dan keseimbangan

${ }^{16}$ Republik Indonesia, “Undang-Undang Nomor 11 Tahun 2020 Tentang Cipta Kerja” (2020).

17 Republik Indonesia, "Undang-Undang Nomor 19 Tahun 2016 Tentang Perubahan Atas Undang-Undang Nomor 11 Tahun 2008 Tentang Informasi Dan Transaksi Elektronik" (2016).

18 Yuli, Sulastri, and Aryanti, "Implementasi Undang-Undang Ketenagakerjaan Dalam Perjanjian Kerja Antara Perusahaan Dan Tenagakerja Di Perseroan Terbatas.”

${ }^{19}$ Apri Amalia, Budiman Ginting, and Yefrizawati Agusmidah, "Analisis Yuridis Perjanjian Kerja Waktu Tertentu Berdasarkan Undang-Undang Ketenagakerjaan Dan Hukum Perjanjian," USU Law Journal 5, no. 1 (2017): 66-76.

${ }^{20}$ Fathur Rahman, "Kajian Teoritis Penerapan Dan Perlindungan Hukum Terhadap Pekerja Dalam Perjanjian Kerja Waktu Tertentu (Pkwt) Menurut Undang-Undang Nomor 13 Tahun 2003 Tentang Ketenagakerjaan (Studi Pada PT. Duta Nichirindo Pratama Kota Tangerang)," Jurnal Surya Kencana Dua: Dinamika Masalah Hukum Dan Keadilan 4, no. 1 (December 2017): 87-106.

${ }^{21}$ (Pamady and Nabiyla Risfa Izzati, 2019) 
kehidupan kerja ${ }^{22}$, perlindungan para pekerja pada era $4.0^{23}$, dan kekuatan hukum perjanjian kerja melalui transaksi elektronik. ${ }^{24}$ Berdasarkan penelitian-penelitian terdahulu yang telah di uraikan di atas, belum ditemukan adanya penelitian yang membahas perihal analisis PKWT pada kasus hubungan hukum antara pengusaha dengan pekerja remote working. Analisis yuridis terhadap PKWT ini bertujuan untuk menemukan format ideal PKWT antara pengusaha dan pekerja dengan konsep remote working berdasarkan UU Cipta Kerja.

\section{B. Perumusan Masalah}

Penelitian ini akan mengidentifikasi dan menganalisis berbagai hal terkait prinsip hukum perjanjian kerja dengan beberapa rumusan masalah sebagai berikut: Pertama, bagaimana pola PKWTdengan konsep Remote Working dalam prespektif UU Cipta Kerja?; Kedua, bagaimana keabsahan PKWTdengan konsep remote working dalam prespektif UU Cipta Kerja?.

\section{METODE PENELITIAN}

Metode penelitian yang digunakan dalam penelitian ini adalah penelitian yuridis normatif yaitu meneliti produk-produk hukum berupa peraturan dengan tetap melihat kenyataan yang terjadi di masyarakat dan berkaitan dengan permasalahan dalam penelitian ini. terjadi di dalam masyarakat. ${ }^{25}$ Bahan hukum yang digunakan dalam penelitian normatif ini meliputi, peraturan perundang-undangan, buku-buku, perjanjian kerja, dan dokumen hukum lainnya. ${ }^{26}$ Metode pendekatan yang digunakan dalam penelitian ini meliputi: 1) Pendekatan perundang-undangan (statuteapproach), yaitu metode dengan cara melakukan analisis pada peraturan

${ }^{22}$ Alan Felstead and Golo Henseke, "Assessing the Growth of Remote Working and Its Consequences for Effort, Well-Being and Work-Life Balance," New Technology, Work and Employment 32, no. 3 (November 2017): 195-212, https://doi.org/10.1111/ntwe.12097.

23 Arie Purnomosidi and Ratna Riyanti, "Perlindungan Bagi Pekerja Di Era Revolusi Industri 4.0 Dalam Perspektif Hubungan Industrial Pancasila," in Prosiding Seminar Nasional Hukum Transendental (Semarang: Universitas Muhammadiyah Surakarta, 2019), 47-56.

${ }^{24}$ Vita Damayanti and Ari Hernawan, "Analisis Yuridis Atas Kekuatan Mengikat Perjanjian Kerja Waktu Tertentu Melalui Transaksi Elektronik (Studi Kasus Putusan Mahkamah Agung No.828/Pdt.Sus/2012, Pada Tingkat Pertama Putusan Pengadilan Hubungan Industrial No.54/PHI.G/2012/PN.JKT.PST)" (Gadjah Mada University, 2014), http://etd.repository.ugm.ac.id/penelitian/detail/78209\#filepdf.

25 Soeryono Soekanto, Penelitian Hukum Normatif (Suatu Tinjauan Singkat) (Jakarta: Rajawali, 1990).

${ }^{26}$ Soejono Soekanto and Sri Mamudji, Penelitian Hukum Normatif Suatu Tinjau Singkat, 8th ed. (Jakarta: Sinar Grafika, 2004). 
perundang-undangan ${ }^{27} ; 2$ ) Pendekatan konsep (conseptual approach), yaitu metode dengan melakukan pengkajian dan pemahaman terhadap konsepkonsep hukum ${ }^{28}$. Teknik yang digunakan untuk menganalisis yaitu dengan menggunakan sistem Interprestasi, seperti penafsiran gramatikal, dan penafsiran sistematis.

\section{PEMBAHASAN}

\section{Pola Perjanjian Kerja Waktu Tertentu dengan Konsep Remote Working}

PKWT merupakan salah satu bentuk perjanjian kerja yang ada di Indonesia. Yunus Shamad dalam Jurnal Fitrhiatus Shalihah berpendapat bahwa perjanjian kerja merupakan bagian dari sumber hukum ketenagakerjaan. ${ }^{29}$ Secara lengkap, Shamad mengidentifikasikan sumber hukum ketenagakerjaan terdiri atas: peraturan perundang-undangan , adat dan kebiasaan, keputusan Pejabat atau Badan Pemerintah, Traktat, Peraturan Kerja, dan Perjanjian Kerja. ${ }^{30}$ Saat ini, UU Ketenagakerjaan dan UU Cipta Kerja merupakan payung hukum dari ketentuan ketenagakerjaan di Indonesia, termasuk ketentuan perjanjian kerja. UU Cipta Kerja merupakan peraturan yang melakukan perubahan pada 31 Pasal, penghapusan pada 29 Pasal, dan penyisipan 13 Pasal baru dalam UU Ketenagakerjaan. Termasuk ketentuan PKWT yang banyak mengalami perubahan di dalam UU Cipta Kerja.

Berdasarkan Pasal 56 UU Cipta Kerja, membedakan Perjanjian kerja ada 2 macam, yaitu perjanjian kerja yang dapat dibuat untuk waktu tertentu (PKWT) atau perjanjian kerja untuk waktu tidak tertentu (PKWTT). Selanjutnya, dijelaskan lebih lanjut pada Pasal 56 ayat (2) dan (3) UU Cipta Kerja bahwa PKWT yaitu perjanjian kerja yang didasarkan pada jangka waktu dan selesainya suatu pekerjaan yang semua dasar tersebut telah ditentukan di dalam Perjanjian Kerja. PKWT pada umumnya masyarakat mengenal sebagai karyawan kontrak, sedangkan Perjanjian kerja waktu tidak tertentu pada umumnya masyarakat mengenal sebagai karyawan tetap. Lebih detail, pengertian keduanya diatur di dalam Pasal 1 Keputusan Menteri Tenaga Kerja dan Transmigrasi Republik Indonesia Nomor Kep.100/MEN/VI/2004 tentang Ketentuan Pelaksanaan Perjanjian Kerja

\footnotetext{
Bayumedia, 2007).

${ }^{29}$ Fithriatus Shalihah, "Perjanjian Kerja Waktu Tertentu (Pkwt) Dalam Hubungan Kerja Menurut Hukum Ketenagakerjaan Indonesia Dalam Perspektif Ham," UIR LAW REVIEW 1, no. 2 (2017): 149-60, https://doi.org/10.25299/uirlrev.2017.1.02.955.

${ }^{30}$ Ibid.
}

${ }^{27}$ Peter Mahmud Marzuki, Penelitian Hukum (Jakarta: Kencana, 2007).

28 Johnny Ibrahim, Teori Dan Metodologi Penelitian Hukum Normatif (Malang: 
Waktu Tertentu. Pasal 1 angka $1^{31}$ menjelaskan bahwa PKWT adalah perjanjian kerja antara pekerja/buruh dengan pengusaha untuk mengadakan hubungan kerja dalam waktu tertentu atau untuk pekerjaan tertentu. Sedangkan pengertian PKWTT dijelaskan pada Pasal 1 angka $2^{32}$ yang memiliki arti: perjanjian kerja antara pekerja/buruh dengan pengusaha untuk mengadakan hubungan kerja yang bersifat tetap.

Berdasarkan kondisi di Indonesia yang berbeda dengan negaranegara maju, negara Indonesia sebagai negara berkembang masih memiliki kecenderungan bahwa para pekerja di Indonesia lebih memilih terikat dalam hubungan kerja yang bersifat tetap pada satu perusahaan. ${ }^{33}$ Pada prinsipnya, Pekerja Waktu Tertentu mengharapakan menjadi Pekerja Waktu Tidak Tertentu/Pekerja Tetap di suatu Perusahaan. Namun, kadangkala dalam praktik, PKWT yang telah melebihi tiga tahun (yang sebelumnya sesuai ketentuan UU Ketenagakerjaan) dan ingin diperpanjang oleh Pengusaha/Pemberi Kerja dibuat dengan cara tidak menyebut perpanjangan Perjanjian Kerja Waktu Tertentu, melainkan dengan cara Pembaharuan Perjanjian Kerja Waktu Tertentu. ${ }^{34}$ Hal ini tentunya melanggar Pasal 59 UU Ketenagakerjaan, tetapi setelah disahkan UU Cipta Kerja, jangka waktu dan pembatasan PKWT ini dihapus dan masih menunggu ketentuan lebih lanjut dalam Peraturan Pemerintah.

Remote working merupakan penamaan lain dari bekerja jarak jauh (telecommuting). Bekerja jarak jauh berkembang seiring waktu yang awalnya dikenal dengan istilah 'electronic homework', setelah itu berkembang menjadi 'telecommuting', kemudian 'flexiwork', dan pada akhirnya penamaan bekerja jarak jauh tersebut berkembang di berbagai tulisa, seperti: 'remote working', 'distance working' atau 'outwork'. ${ }^{35}$ Selanjutnya, menurut Konradt, Schmook, dan Malecke dalam Oswar Mungkasa berpendapat bahwa bekerja jarak jauh merupakan metode bekerja dalam sebuah organisasi yang dilaksanakan sebagian atau seluruhnya di luar kantor konvensional dengan bantuan layanan telekomunikasi dan

31 Minister of Manpower and Transmigration of the Republic of Indonesia, "Keputusan Menteri Tenaga Kerja Dan Transmigrasi Republik Indonesia Nomor KEP.100/MEN/VI/2004 Tentang Ketentuan Pelaksanaan Perjanjian Kerja Waktu Tertentu” (2004).

${ }^{32} \mathrm{Ibid}$.

${ }^{33}$ Fithriatus Shalihah. Op.Cit. Page 155

${ }^{34}$ Sunarno, "BEBERAPA MASALAH PADA PERJANJIAN KERJA WAKTU TERTENTU DAN SOLUSINYA,” Wacana Hukum 3, no. 2 (2009): 19-32, http://ejurnal.unisri.ac.id/index.php/Wacana/article/viewFile/310/272.

35 Oswar Mungkasa, "Bekerja Jarak Jauh (Telecommuting): Konsep, Penerapan Dan Pembelajaran,” 1 (Jakarta, 2020), http://workingpapers.bappenas.go.id/index.php/bwp/article/download/52/43/. 
informasi. ${ }^{36}$ Dengan demikian, Remote working terdapat ciri khas yang membedakan dengan office working, yaitu: tempat/lokasi bekerja yang dilakukan diluar kantor, waktu/jadwal yang fleksibel, dan adanya pemnafaatan teknologi komunikasi dan informasi modern.

Remote working memang memiliki dampak positif maupun negatif ${ }^{37}$ kepada Pekerja dan Pengusaha, namun keberadaanya tetap perlu dikaji lebih lanjut dalam lingkup hukum ketenagakerjaan, terutama pada perjanjian. Selain itu, pada dasarnya, Remote Working menimbulkan suatu hubungan yangn memiliki unsur pekerjaan, upah, dan perintah. ${ }^{38}$ Perjanjian kerja membuat hubungan hukum antara pekerja dan pengusaha tersebut memiliki legalitas yang kuat di hadapan hukum. Apalagi jika pekerjaan itu merupakan pekerjaan dengan waktu tertentu yang oleh Pasal 57 UU Cipta Kerja harus memiliki PKWT secara tertulis. Namun, ketentuan tertulis dalam UU Cipta Kerja ini tidak memiliki akibat hukum jika tidak dilaksanakan oleh Pihak Pemberi Kerja, Hal ini berbeda dengan Pasal 57 UU Ketenagakerjaan yang mengatur bahwa jika tidak dibuat secara tertulis maka PKWT berubah menjadi PKWTT.

PKWT dengan konsep remote working sebagaimana yang dilakukan Perusahaan A dan Pekerja B yang pada prinsipnya sama dengan PKWT pada umumnya (office working), sebagaimana yang telah disampaikan sebelumnya bahwa hubungan kerja antara Pengusaha dan Tenaga Kerja harus tunduk pada UU Ketenagakerjaan karena dibuat pada tahun 2019. Namun, perjanjian ini juga dapat dikaji dengan prespektif UU Cipta Kerja sebagai aturan baru dalam Hukum Ketenagakerjaan. Berdasarkan hasil wawancara dengan Pekerja B, perjanjian kerja yang dilakukan antara Pekerja B dan Perusahaan A dilakukan secara online atau dalam bentuk

\section{${ }^{36}$ Ibid.Page 2}

37 Ravi S Gajendran and David A Harrison, "The Good, the Bad, and the Unknown About Telecommuting: Meta-Analysis of Psychological Mediators and Individual Consequences," Journal of Applied Psychology 92, no. 6 (2007): 1524-41, https://doi.org/10.1037/0021-9010.92.6.1524. Telecommuting also had beneficial effects

on more distal outcomes, such as job satisfaction, performance, turnover intent, and role stress. Telecommuting has a clear upside: small but favorable effects on perceived autonomy, work- family conflict, job satisfaction, performance, turnover intent, and stress. Contrary to expectations in both academic and practitioner literatures, telecommuting also has no straightforward, damaging effects on the quality of workplace relationships or perceived career prospects. However, there is a downside of higher intensity telecommuting in that it does seem to send coworker (but not supervisor) relationships in a harmful direction. Some of the complexities of these consequences have yet to be explored, but the evidence and theory reviewed here suggest that they can be managed effectively through informed human resources policies.

38 Republik Indonesia, Undang-Undang Nomor 13 Tahun 2013 tentang 
surat elektronik melalui E-mail. Pola PKWT pada perjanjian kerja Nomor 17/PKWT/PT-A/VIII/2019 meliputi:

1) Pembukaan, yang berisi waktu pembuatan kontrak;

2) Komparisi, yang berisi identitas dan kedudukan bertindak para pihak dalam perjanjian kerja;

3) Premis, yang menerangkan posisi dan maksud utama dari para pihak dibuatnya perjanjian kerja;

4) Isi Perjanjian, yang berisi 11 Pasal yang mengatur tentang: waktu perjanjian, tugas dan penempatan, masa percobaan, hak dan kewajiban pihak pertama, hak dan kewajiban Pihak Kedua, Waktu Kerja dan Cuti Tahunan, Upah Pokok-Tunjangan-dan Pajak Penghasilan, Kerahasiaan, berakhirnya perjanjian kerja, Perselisihan, dan Penutup. Bagian isi perjanjian inilah yang perlu dikaji lebih lanjut terhadap UU Ketenagakerjaan.

5) Tanda tangan para pihak.

Pola PKWT pada dasarnya telah diatur pada Pasal 54 UU Ketenagakerjaan dan ketentuan ini tidak mengalami perubahan di dalam UU Cipta Kerja. Pada pasal 54 ini mengatur hal-hal yang minimal harus ada di dalam perjanjian kerja. Terkait hal ini, berikut merupakan pembandingan sistematika perjanjian kerja berdasarkan UU Ketenagakerjaan dengan sistematika PKWT Nomor 17/PKWT/PT-A/VIII/2019:

\begin{tabular}{|l|c|l|}
\hline \multicolumn{1}{|c|}{$\begin{array}{c}\text { Pembanding (Pasal 54 } \\
\text { UU ketenagakerjaan) }\end{array}$} & $\begin{array}{c}\text { Isi Perjanjian } \\
\text { Nomor } \\
\text { 17/PKWT/PT- } \\
\text { A /VIII/2019 }\end{array}$ & \multicolumn{1}{|c|}{ Keterangan } \\
\hline $\begin{array}{l}\text { nama, alamat perusahaan, } \\
\text { dan jenis usaha }\end{array}$ & Ada & lengkap \\
\hline $\begin{array}{l}\text { nama, jenis kelamin, umur, } \\
\text { dan alamat pekerja/buruh }\end{array}$ & Ada & lengkap \\
\hline jabatan atau jenis pekerjaan & Ada & Software Developer \\
\hline $\begin{array}{l}\text { tempat pekerjaan } \\
\text { Ada }\end{array}$ & $\begin{array}{l}\text { Ada, namun tidak menunjukan } \\
\text { secara tegas dan tidak } \\
\text { menggambarkan konsep remote } \\
\text { working. Meskipun pada } \\
\text { kenyataannya dilakukan dengan } \\
\text { Remote Working }\end{array}$ \\
\hline $\begin{array}{l}\text { besarnya upah dan cara } \\
\text { pembayarannya }\end{array}$ & Ada & $\begin{array}{l}\text { Diuraikan lengkap terkait Upah } \\
\text { Pokok, Tunjangan dan Pajak } \\
\text { Penghasilan }\end{array}$ \\
\hline $\begin{array}{l}\text { syarat-syarat kerja yang } \\
\text { memuat hak dan kewajiban } \\
\text { pengusaha dan pekerja/ } \\
\text { buruh }\end{array}$ & Ada & $\begin{array}{l}\text { Hak dan Kewajiban Pihak } \\
\text { Kesatu } \\
\text { Hak dan kewajiban Pihak Kedua }\end{array}$ \\
\hline mulai dan jangka waktu & Ada & Dalam kurun waktu 2 (dua) \\
\hline
\end{tabular}




\begin{tabular}{|c|c|c|}
\hline berlakunya perjanjian kerja & & tahun \\
\hline $\begin{array}{l}\text { tempat dan tanggal } \\
\text { perjanjian kerja dibuat }\end{array}$ & $\begin{array}{l}\text { Ada, dengan } \\
\text { catatan }\end{array}$ & $\begin{array}{l}\text { Hanya tanggal, Tidak } \\
\text { menjelaskan tempat perjanjian } \\
\text { kerja dibuat }\end{array}$ \\
\hline $\begin{array}{l}\text { tanda tangan para pihak } \\
\text { dalam perjanjian kerja }\end{array}$ & $\begin{array}{l}\text { Ada, dengan } \\
\text { catatan }\end{array}$ & $\begin{array}{l}\text { Hanya Pihak Kedua sebagai } \\
\text { Pekerja (selanjutnya tidak ada } \\
\text { pengembalian perjanjian dengan } \\
\text { tanda tangan lengkap dari } \\
\text { Perusahaan) yang mana hal ini } \\
\text { bertentangan dengan pasal } 54 \\
\text { ayat } 3 \text { UU Ketenagakerjaan. }\end{array}$ \\
\hline
\end{tabular}

Tabel 1 Pola Perjanjian Kerja Menurut UU Ketenagakerjaan dengan PKWT Nomor 17/PKWT/PT-A/VIII/2019

Berdasarkan PKWT pada perjanjian kerja Nomor 17/PKWT/PTA/VIII/2019 tentunya tidak memiliki perbedaan dengan perjanjian kerja pada umumnya. Terkait klausula yang menunjukan tempat kerja pun masih tertuliskan nama Perusahaan. Dengan kata lain, tidak ada klausula khusus terkait sistem kerja Remote Working. Berdasarkan prinsip Pacta Sunt Servanda, maka Seharusnya, Perjanjian kerja harus dibuat sesuai dengan sistem kerja yang digunakan sehingga tidak menimbulkan permasalahan hukum di kemudian hari. Pada bagian tempat pekerjaan dalam PKWT dengan konsep remote working dapat diuraikan lebih lanjut terkait sistem kerja yang dilakukan secara jarak jauh. Hal ini juga dapat diatur lebih lanjut di dalam bagian Hak dan kewajiban sehingga jelas konsep Remote Working tersebut yang digunakan di dalam PKWT yang disepakati.

\section{Keabsahan PKWT Dengan Konsep Remote Working Dalam Prepektif Undang-Undang Cipta Kerja}

Mengkaji keabsahan PKWT dengan konsep Remote Working yang tercantum di dalam PKWTNomor 17/PKWT/PT-A/VIII/2019 merupakan salah satu upaya untuk menganalisis dan mengetahui hal-hal yang seharusnya menjadi pedoman bagi Para Pemberi Kerja/Pengusaha dan Pekerja untuk saling bersepakat dengan memperhatikan kepentingan masing-masing yang tidak merugikan satu sama lain dan tidak melanggar ketentuan peraturan perundang-undangan. Perjanjian kerja antara Perusahaan A dengan Pekerja B yang tercantum dalam PKWT Nomor 17/PKWT/PT-A/VIII/2019 terindentifikasi bertentangan dengan UU Ketenagakerjaan dan UU Cipta Kerja. Selain itu, keabsahan PKWT ini juga perlu dikaji dengan aspek hukum diluar hukum ketenagakerjaan yang berlaku di Indonesia seperti KUHPerdata sebagai ketentuan umum hukum perjanjian dan UU ITE sebagai aturan transaksi elektronik. Hal ini dilakukan agar kekuatan PKWT tersebut kuat dihadapan hukum dan dapat 
dijadikan sebagai alat bukti apabila terjadi sengketa antara Perusahaan dan Pekerja.

Pada praktiknya, perjanjian kerja (baik PKWT dan PKWTT) dibuat secara sepihak oleh Pemberi kerja/Pengusaha tanpa adanya negoisasi dengan Calon Pekerjanya. Calon Pekerja hanya diberikan pilihan menyepakati atau tidak menyepakati perjanjian kerja tersebut. Meskipun, berdasarkan Pasal 54 ayat 2 UU Ketenagakerjaan menentukan bahwa Ketentuan dalam perjanjian kerja tidak boleh bertentangan dengan peraturan perusahaan, perjanjian kerja bersama, dan peraturan perundang-undangan yang berlaku. Namun, hal yang menjadi perhatian yaitu apakah substansi perjanjian kerja tersebut memuat klausula yang dilarang oleh UU Ketenagakerjaan dan UU Cipta Kerja, ketidakrasionalan, dan ketidakpatutan.

Ketentuan perjanjian kerja di dalam UU Ketenagakerjaan dan UU Cipta Kerja bersifat memaksa, artinya para pihak yang terikat dalam perjanjian-kerja tidak dapat membuat perjanjian kerja menyimpang dari ketentuan peraturan perundangundangan ketenagakerjaan. ${ }^{39}$ Ketentuan PKWT di dalam UU Ketenagakerjaan harus diperhatikan pengusaha dalam membuat isi dari perjanjian. Hal ini disebabkan keterlibatan pemerintah di dalam mengawasi Perjanjian kerja Waktu Tertentu. Pemerintah Indonesia serius melindungi hak Pekerja dengan menerapkan sanksi kepada Pengusaha yang mencoba mengabaikan kewajibannya terhadap hak-hak Para Pekerja, seperti memberikan jaminan sosial kepada Pekerja ${ }^{40}$.

UU Ketenagakerjaan memberikan karakteristik perjanjian yang dikategorikan sebagai PKWT, yaitu: (Pasal 59 UU Cipta Kerja)

a. pekerjaan yang sekali selesai atau yang sementara sifatnya;

b. pekerjaaan yang diperkirakan penyelesaiannya dalam waktu yang tidak terlalu lama;

c. pekerjaan yang bersifat musiman;

d. pekerjaan yang berhubungan dengan produk baru, kegiatan baru, atau produk tambahan yang masih dalam percobaan atau penjajakan; atau

e. pekerjaan yang jenis dan sifat atau kegiatannya bersifat tidak tetap.

f. pekerjaan yang tidak dapat diadakan untuk pekerjaan yang bersifat tetap.

39 Sunarno, "BEBERAPA MASALAH PADA PERJANJIAN KERJA WAKTU TERTENTU DAN SOLUSINYA.” Page 20

${ }^{40}$ Nur Putri Hidayah, "Comparative Study of Legal Protection for Migrant Workers in Participation of Social Security Programs in Indonesia and Singapore | Hidayah | Legality : Jurnal Ilmiah Hukum," Legality : Jurnal Ilmiah Hukum, 2020, https://doi.org/10.22219/Ijih.v2i1.11786. 
Perjanjian kerja pada umumnya dibuat berdasarkan persyaratan yang diatur dalam Pasal 1320 KUHPerdata. Pasal 1320 KUHPerdata merupakan dasar hukum untuk menentukan keabsahan suatu perjanjian. Jika mengkaitkan Pasal 1320 KUHPerdata dengan Pasal 52 (1) UU Ketenagakerjaan, perjanjian kerja yang sah dihadapan hukum adalah perjanjian yang memenuhi empat syarat, yakni: 1) kesepakatan para pihak; 2) kecakapan para pihak melakukan perbuatan hukum; 3) adanya obyek tertentu yaitu pekerjaan yang diperjanjikan; dan 4) sebab/causa yang halal yaitu pekerjaan tersebut tidak bertentangan dengan ketertiban umum, kesusilaan, dan peraturan perundang-undangan. Sebagaimana sifat persyaratan pada Pasal 1320 KUHPerdata maka syarat pada Pasal 52 (1) UU Ketenagakerjaan juga dapat dikategorikan menjadi dua syarat, yaitu syarat subyektif dan syarat obyektif. Syarat subyektif meliputi syarat yang terkait subyek perjanjian yaitu syarat kesepakatan dan kecakapan para pihak. Sedangkan, syarat obyektif mencakup yang terkait obyek perjanjian, yaitu adanya obyek tertentu dan causa/sebab yang halal. Tidak terpenuhinya salah satu syarat tersebut mengakibatkan perjanjian yang dibuat dapat dibatalkan atau batal demi hukum. Hal ini sejalan pula dengan ketentuan Pasal 52 ayat (2) dan (3) UU Ketenagakerjaan juga sama dengan ketentuan di KUHPerdata yaitu dapat dibatalkan atau batal demi hukum. Pengidentifikasian pemenuhan syarat sah perjanjian tersebut tentunya harus dilakukan oleh para pihak di awal pembuatan perjanjian atau pada tahapan persiapan perancangan kontrak. Dengan demikian, seharusnya para pihak sebelum bersepakat dalam perjanjian (dalam hal ini adalah perjanjian kerja) telah memahami terlebih dahulu terhadap siapa ia telah melakukan kesepakatan dan mengetahui secara jelas causa dan obyek kesepakatan. ${ }^{41}$

Berdasarkan perjanjian Pekerja B dengan Perusahaan A Nomor: 17/PKWT/PT-A/VIII/2019, ditemukan beberapa permasalahan dalam hal kesepakatan dan causa yang halal. Sedangkan, syarat Kecakapan dan obyek tertentu telah dipenuhi sesuai ketentuan yang ada di dalam KUHPerdata dan Pasal 52 (1) KUHPerdata. Berikut permasalahan terkait keabsahan perjanjian kerja antara Pekerja $\mathrm{B}$ dengan Perusahaan A Nomor 17/PKWT/PT-A/VIII/2019:

1) Tidak ada pembubuhan tanda tangan pengusaha/Pemberi Kerja dalam PKWT sebagai bukti kesepakatan.

Mengenai kesepakatan di dalam Perjanjian dapat dimaknai sebagai kesadaran untuk saling menjamin terpenuhinya hak dan kewajiban

41 Isdian Anggraeny, Tongat, and Wardah Dinnar Rahmadanti, "Urgensi Pelaksanaan Tahapan Persiapan Penyusunan Kontrak Oleh Pelaku Bisnis Dalam Mengkontruksi Hubungan Bisnis," Yurispruden 3 (2020): 1-11, http://riset.unisma.ac.id/index.php/yur/article/view/5013. 
masing-masing pihak. Kesepakatan merupakan langkah awal para pihak mengikatkan diri dalam perjanjian. Oleh karena itu, sebagaimana dinyatakan oleh Kartini Muljadi dan Gunawan Widjaja dalam Glenn Biondi bahwa perjanjian yang mengikat dan berlaku bagi para pihak pada prinsipnya tidak memerlukan suatu formalitas. ${ }^{42}$ Namun, perjanjian yang merupakan bagian dari perbuatan hukum tertentu tentunya harus tunduk pula terhadap peraturan perundang-undangan lainnya, seperti yang terjadi di dalam UU Ketenagakerjaan yang mewajibkan bahwa PKWT harus dibuat secara tertulis. Hal ini tentunya juga untuk menjaga kepentingan Pekerja dan Pengusaha/Pemberi Kerja di kemudian hari. Guna mencapai kesepakatan yang sah secara hukum dan melindungi kepentingan masing-masing individu, para pihak saat melakukan persesuaian kehendak harus memperhatikan beberapa faktor, yaitu penawaran kehendak kepada pihak lain, penyataan kehendak secara tegas, penerimaan kehendak dari orang lain, pernyataan penerimaan kehendak dari orang lain, penerapan prinsip kehati-hatian dengan berlandaskan itikad baik, dan penerapan Pasal 1321 KUH Perdata. ${ }^{43}$

Persetujuan PKWT antara Pekerja B dengan Perusahaan A Nomor 17/PKWT/PT-A/VIII/2019 dapat diketahui melalui bukti tanda tangan di dalam perjanjian kerja. Bukti tanda tangan inilah yang menunjukan bahwa para pihak telah menyetujui dan mengetahui isi dari perjanjian. Selain itu, Tanda tangan yang tercantum di dalam perjanjian merupakan bentuk konsensus/kesepakatan sekaligus kesengajaan antara kedua belah pihak. ${ }^{44}$ Namun, di dalam PKWT Nomor 17/PKWT/PTA/VIII/2019 hanya terdapat tanda tangan Pekerja B sebagai Pihak Pekerja. Pihak Pekerja tidak menerima pengembalian perjanjian kerja yang telah ditandatangani pihak Perusahaan. Padahal, telah tercantum dalam Pasal 11 (Penutup) ayat 3 PKWT Nomor: 17/PKWT/PT-

${ }^{42}$ Glenn Biondi, "Analisis Yuridis Keabsahan Kesepakatan Melalui Surat Elektronik (E-Mail) Berdasarkan Hukum Indonesia," accessed June 22, 2020, https://media.neliti.com/media/publications/164959-ID-none.pdf.

${ }^{43}$ Isdian Anggraeny and Sholahuddin Al-Fatih, "Kata Sepakat Dalam Perjanjian Dan Relevansinya Sebagai Upaya Pencegahan Wanprestasi," De Lega Lata 5 (2020): 57-66, http://jurnal.umsu.ac.id/index.php/delegalata/article/view/3446.

${ }^{44}$ Erwin Kusnul Kotimah and Lukman Santoso, "Urgensi Tanda Tangan Dan Materai Dalam Memberikan Kepastian Hukum Terhadap Kontrak Waralaba (Franchise) The Urgency of Signatures and Stamps on Giving for Legal Certainty toward Franchise Contracts," Holrev 1, no. 1 (2017): 43-63, http://ojs.uho.ac.id/index.php/holrev/. 
A/VIII/2019 bahwa perjanjian kerja tersebut dibuat rangkap dua yaitu satu perjanjian untuk Pihak Pertama dan satu Pihak untuk Pihak Kedua yang masing-masing mempunyai kekuatan hukum yang sama. Meskipun, faktanya hingga saat ini pelaksanaan perjanjian kerja diantara Pekerja B dengan Perusahaan A berjalan sebagai mestinya sesuai yang telah terurai di dalam perjanjian.

Hal ini tidak akan menjadi permasalahan hukum jika para pihak beritikad baik dan menjalankan hak dan kewajiban dengan sebagaimana mestinya. Namun, akan berbeda jika ternyata pada saat pelaksanaan perjanjian terdapat permasalahan dari salah satu pihak atau ternyata tidak beritikad baik. Perjanjian kerja Nomor 17/PKWT/PT-A/VIII/2019 merupakan perjanjian yang proses lamaran pekerjaan sampai dengan kesepakatan dalam perjanjiannya dilakukan secara online (transaksi elektronik) karena Pemberi kerja dan Calon Pekerja berada di tempat yang berbeda. Dasar hukum dalam pelaksanaan transaksi elektronik tersebut tidak boleh bertentangan dengan Undang-Undang Informasi dan Transaksi Elektronik dan Peraturan Pemerintah Nomor 82 Tahun 2012 tentang Penyelenggaraan Sistem Dan Transaksi Elektronik. Kedua dasar hukum tersebut merupakan bagian aturan yang menyelesaikan permasalahan jika transaksi elektronik ini menimbulkan sengketa, salah satunya terkait pembuktian transaksi elektronik.

Selanjutnya, Pasal 11 ayat (1) UU Informasi dan Transaksi Elektronik juga mengatur bahwa tanda tangan elektronik yang memiliki kekuatan hukum dan memiliki akibat hukum yang sah harus memenuhi persyaratan sebagai berikut:

a) data pembuatan Tanda Tangan Elektronik terkait hanya kepada Penanda Tangan;

b) data pembuatan Tanda Tangan Elektronik pada saat proses penandatanganan elektronik hanya berada dalam kuasa Penanda Tangan;

c) segala perubahan terhadap Tanda Tangan Elektronik yang terjadi setelah waktu penandatanganan dapat diketahui;

d) segala perubahan terhadap Informasi Elektronik yang terkait dengan Tanda Tangan Elektronik tersebut setelah waktu penandatanganan dapat diketahui;

e) terdapat cara tertentu yang dipakai untuk mengidentifikasi siapa Penandatangannya; dan

f) terdapat cara tertentu untuk menunjukkan bahwa Penanda Tangan telah memberikan persetujuan terhadap Informasi Elektronik yang terkait. 
Memperhatikan ketentuan Pasal 11 ayat 1 UU ITE tersebut, maka Tanda tangan hasil scan dianggap sebagai tanda tangan elektronik yang memiliki kekuatan hukum dan akibat hukum yang sah apabila dapat memenuhi Pasal 11 ayat (1) UU ITE. Oleh karena itu, jika terjadi penampikan terhadap tanda tangan elektronik maka pembuktiannya melalui pembuktian syarat formil yang diatur pada pasal 11 ayat (1) UU ITE. Jika dikaitkan dengan keberadaan tanda tangan hasil scan sebagaimana yang dilakukan oleh Pihak Kedua dalam Perjanjian Nomor 17/PKWT/PT-A/VIII/2019 maka akan cukup sulit membuktikan sah/tidaknya tanda tangan hasil scan tersebut. Kekuatan hukum hasil scan tanda tangan basah sangat rendah, karena fungsi autentikasinya sangat sulit untuk dipenuhi serta kekuatan nilai pembuktiannya relatif lemah. ${ }^{45}$ Dengan demikian, kedudukan perjanjian kerja tersebut tidak memiliki kekuatan hukum, baik dari KUHPerdata, UU Ketenagakerjaan, UU Hak Cipta, maupun UU ITE. Dengan kata lain, para pihak, baik Pekerja maupun Pengusaha, tidak mendapatkan perlindungan secara hukum karena tidak memenuhi syarat formal yang telah ditentukan oleh aturan perundang-undangan.

2) Tidak terpenuhinya causa halal akibat tidak memenuhi ketentuan peraturan perundang-undangan ketenagakerjaan

Mengenai sebab yang halal diatur dalam Pasal 1335 sampai dengan Pasal 1337 KUHPerdata. Sebagaimana diatur di dalam Pasal 1337 KUHPerdata, Sebab yang halal mengandung makna bahwa perjanjian yang dibuat oleh para pihak harus sesuai dengan hukum yang berlaku dan tidak melanggar kesusilaan atau ketertiban umum. Jika diuraikan lebih lanjut, sebab yang halal dalam perjanjian mengandung makna sebagai berikut: ${ }^{46}$

1) Klausa yang halal berarti isi dari perjanjian itu tidak bertentangan dengan ketertiban umum, kesusilaan, dan undang-undang; ${ }^{47}$

\footnotetext{
45 PT Privy Identitas Digital (PrivyID), "Ulasan Lengkap: Cara Mengidentifikasi Tanda Tangan Elektronik Palsu," 2020, https://www.hukumonline.com/klinik/detail/ulasan/1t5d689c0cc9d81/caramengidentifikasi-tanda-tangan-elektronik-palsu.

46 Tri Wahyu Surya Lestari and Lukman Santoso, "Komparasi Syarat Keabsahan 'Sebab Yang Halal' Dalam Perjanjian Konvensional Dan Perjanjian Syariah," Yudisia : Jurnal Pemikiran Hukum Dan Hukum Islam 8, no. 2 (April 8, 2018): 281-98, https://doi.org/10.21043/YUDISIA.V8I2.3240.

${ }^{47}$ Fajar Bayu Setiawan in Tri Wahyu Surya Lestari and Lukman Santoso, Ibid.
} 
2) Sebab dikatakan palsu jika diadakan untuk menutupi sebab yang sebenarnya;

3) Sebab dikatakan terlarang jika bertentangan dengan undang-undang, kesusilaan, dan ketertiban umum; dan

4) Suatu perjanjian tanpa sebab, jika tujuan yang dimaksudkan oleh para pihak pada saat dibuatnya perjanjian tidak akan tercapai. ${ }^{48}$

Berbeda dengan syarat subyektif, syarat terkait obyek tertentu dan kausa halal merupakan syarat obyektif dalam pemenuhan syarat sah perjanjian. Apabila syarat obyektif ini tidak dipenuhi oleh para pihak maka perjanjian tersebut dapat batal demi hukum (null and void). Sebagaimana dinyatakan oleh Elly Erawati dan Herlien Budiono bahwa perjanjian batal demi hukum berarti perjanjian tersebut dari semula tidak pernah dilahirkan, dan dengan demikian tidak pernah ada suatu perikatan. ${ }^{49}$

Berkaitan dengan Perjanjian Kerja Waktu Tertentu antara Pekerja B dengan Perusahaan A Nomor 17/PKWT/PT-A/VIII/2019, didapatkan ketentuan yang melanggar UU Ketenagakerjaan. Berdasarkan perjanjian tersebut ditemukan ketentuan terkait Masa Percobaan yang terdapat di dalam Pasal 3 ayat 1 PKWT Nomor 17/PKWT/PTA/VIII/2019 yang menyatakan bahwa: "Pihak Kedua wajib menjalani Masa Percobaan untuk jangka waktu paling lama 3 (tiga) bulan sejak tanggal 1 Agustus 2019 sampai dengan tanggal 1 November 2019”. Hal ini tentunya bertentangan dengan ketentuan UU Cipta Kerja yang tercantum di dalam Pasal 58 yang menyatakan bahwa PKWT tidak dapat mensyaratkan adanya masa percobaan dan jika ini dicantumkan maka masa percobaan kerja yang disyaratkan ini batal demi hukum dan masa kerja tetap dihitung.

Berdasarkan prespektif UU Cipta kerja dan UU Ketenagakerjaan telah diketahui rumusan mana saja pada PKWT antara Pekerja B dengan Perusahaan A yang tidak sesuai dengan Hukum Ketenagakerjaan, yaitu: tidak ada pembubuhan tanda tangan pengusaha/Pemberi Kerja dalam PKWT sebagai bukti kesepakatan dan Tidak terpenuhinya causa halal akibat tidak memenuhi ketentuan peraturan perundang-undangan ketenagakerjaan. Kedua kesalahan tersebut tentunya mewakili kualitas PKWT dalam memenuhi beberapa aturan hukum sebagaimana terurai di atas, terutama terkait syarat sah perjanjian kerja. Dengan tidak terpenuhinya syarat-syarat

${ }^{48}$ Eka Astri Maerisa in Tri Wahyu Surya Lestari and Lukman Santoso, Ibid.

49 Elly Erawati and Herlien Budiono, Penjelasan Hukum Tentang Kebatalan Perjanjian (Jakarta: Nasional Legal Reform Program, 2010). 
sah perjanjian memberikan akibat hukum, yaitu dapat dibatalkan dan/atau batal demi hukum.

Dengan demikian, dalam pembuatan PKWT dengan konsep remote working perlu memperhatikan 3 aspek hukum, yaitu, KUHPerdata, UU Cipta Kerja berikut dengan UU Ketenagakerjaan, dan UU ITE. Secara singkat ada 4 aspek yang harus diperhatikan para pihak dalam pembuatan PKWT yaitu: 1) PKWT yang tertulis dan disepakati secara sah melalui media elektronik,; 2) hak dan kewajiban dari masing-masing pihak sebagaimana yag telah diatur di dalam UU Ketenagakerjaan dan UU Cipta Kerja; 3) Penguraian secara jelas system kerja Remote Working dalam PKWT; dan 4) hal-hal yang dilarang oleh Hukum terkait PKWT. Pengesahan Perjanjian Kerja yang dalam hal ini penandatanganan para pihak perlu memperhatikan UU ITE sehingga kekuatan hukum perjanjian kerja yang dilakukan secara elektronik itu menjadi kuat dan dapat dijadikan sebagai alat bukti yang sah.

\section{KESIMPULAN}

1. PKWT dengan konsep Remote Working pada prinsipnya sama dengan PKWT pada umumnya (Office Working) yang harus tunduk dengan ketentuan UU Ketenagakerjaan dan UU Cipta Kerja. Berdasarkan hasil wawancara dengan Pekerja B, kesepakatan PKWT antara Perusahaan A dan Pekerja B dilakukan melalui media elektronik. Pola PKWT Nomor 17/PKWT/PT-A/VIII/2019 meliputi: Pembukaan, yang berisi waktu pembuatan kontrak; Komparisi yang berisikan identitas para pihak; Premis yang menjelaskan terkait maksud dari tujuan perjanjian kerja; Isi Perjanjian yang berisikan 11 Pasal yaitu: waktu perjanjian, tugas dan penempatan kerja, masa percobaan pekerja, hak dan kewajiban pihak pertama, hak dan kewajiban Pihak Kedua, Waktu Kerja dan Cuti Tahunan, Upah Pokok-Tunjangan dan Pajak Penghasilan, Kerahasiaan, berakhirnya perjanjian kerja, Perselisihan, dan diakhiri dengan Penutup. Bagian isi perjanjian inilah yang perlu dikaji lebih lanjut terhadap UU Ketenagakerjaan dan UU Cipta Kerja; Tanda tangan para pihak.

2. Pembuatan PKWT dengan konsep Remote Working perlu memperhatikan 3 aspek hukum, yaitu, KUHPerdata, UU Cipta Kerja berikut dengan UU Ketenagakerjaan, dan UU ITE. Secara singkat terdapat 4 aspek yang harus diperhatikan para pihak dalam pembuatan PKWT yaitu: 1) PKWT yang tertulis dan disepakati secara sah melalui media elektronik,; 2) hak dan kewajiban dari masing-masing pihak sebagaimana yag telah diatur di dalam UU Ketenagakerjaan dan UU Cipta Kerja; 3) Penguraian secara jelas system kerja Remote Working dalam PKWT; dan 4) hal-hal yang dilarang oleh Hukum terkait PKWT. 


\section{DAFTAR PUSTAKA \\ Buku}

Erawati, Elly, and Herlien Budiono. Penjelasan Hukum Tentang Kebatalan Perjanjian. Jakarta: Nasional Legal Reform Program, 2010.

Greenbaum, Zara. "The Future of Remote Work." American Psycological Associatio, 2019.

Ibrahim, Johnny. Teori Dan Metodologi Penelitian Hukum Normatif. Malang: Bayumedia, 2007.

Marzuki, Peter Mahmud. Penelitian Hukum. Jakarta: Kencana, 2007.

Soekanto, Soejono, and Sri Mamudji. Penelitian Hukum Normatif Suatu Tinjau Singkat. 8th ed. Jakarta: Sinar Grafika, 2004.

Soekanto, Soeryono. Penelitian Hukum Normatif (Suatu Tinjauan Singkat). Jakarta: Rajawali, 1990.

\section{Jurnal}

Amalia, Apri, Budiman Ginting, and Yefrizawati Agusmidah. "Analisis Yuridis Perjanjian Kerja Waktu Tertentu Berdasarkan Undang-Undang Ketenagakerjaan Dan Hukum Perjanjian." USU Law Journal 5, no. 1 (2017): 66-76.

Anggraeny, Isdian, and Sholahuddin Al-Fatih. "Kata Sepakat Dalam Perjanjian Dan Relevansinya Sebagai Upaya Pencegahan Wanprestasi." De Lega Lata 5 (2020): 57-66. http://jurnal.umsu.ac.id/index.php/delegalata/article/view/3446.

Anggraeny, Isdian, Tongat, and Wardah Dinnar Rahmadanti. "Urgensi

Pelaksanaan Tahapan Persiapan Penyusunan Kontrak Oleh Pelaku Bisnis Dalam Mengkontruksi Hubungan Bisnis.” Yurispruden 3 (2020): 1-11. http://riset.unisma.ac.id/index.php/yur/article/view/5013.

Biondi, Glenn. "Analisis Yuridis Keabsahan Kesepakatan Melalui Surat Elektronik (E-Mail) Berdasarkan Hukum Indonesia." Accessed June 22, 2020. https://media.neliti.com/media/publications/164959-IDnone.pdf.

Bloom, Nicholas, James Liang, John Roberts, and Zcichan Jenny Yang. "Does working from home work? Evidence from a chinese experiment," $2013 . \quad$ file:///D:/jurnal/jurnal 2020/ICLIS/BAHAN/w18871.pdf\%250D.

Damayanti, Vita, and Ari Hernawan. "Analisis Yuridis Atas Kekuatan Mengikat Perjanjian Kerja Waktu Tertentu Melalui Transaksi Elektronik (Studi Kasus Putusan Mahkamah Agung No.828/Pdt.Sus/2012, Pada Tingkat Pertama Putusan Pengadilan Hubungan Industrial No.54/PHI.G/2012/PN.JKT.PST).” Gadjah Mada 
University, 2014.

http://etd.repository.ugm.ac.id/penelitian/detail/78209\#filepdf.

Eddleston, Kimberly A., and Jay Mulki. "Toward Understanding Remote Workers' Management of Work-Family Boundaries: The Complexity of Workplace Embeddedness." Group \& Organization Management 42, no. 3 (June 2017): 346-87. https://doi.org/10.1177/1059601115619548.

Felstead, Alan, and Golo Henseke. "Assessing the Growth of Remote Working and Its Consequences for Effort, Well-Being and Work-Life Balance." New Technology, Work and Employment 32, no. 3 (November 2017): 195-212. https://doi.org/10.1111/ntwe.12097.

Gajendran, Ravi S, and David A Harrison. "The Good, the Bad, and the Unknown About Telecommuting: Meta-Analysis of Psychological Mediators and Individual Consequences." Journal of Applied Psychology 92, no. 6 (2007): 1524-41. https://doi.org/10.1037/00219010.92.6.1524.

Hardill, Irene, and Anne Green. "Remote Working - Altering the Spatial Contours of Work and Home in the New Economy." New Technology, Work and Employment 18, no. 3 (November 2003): 212-22. https://doi.org/10.1111/1468-005X.00122.

Haryanto, Totok Dwinur. "Hubungan Hukum Yang Menimbulkan Hak Dan

Kewajiban Dalam Kontrak Bisnis.” Wacana Hukum IX (2010): 85-97. http://ejurnal.unisri.ac.id/index.php/Wacana/article/view/306/268.

Hidayah, Nur Putri. "Comparative Study of Legal Protection for Migrant Workers in Participation of Social Security Programs in Indonesia and Singapore | Hidayah | Legality: Jurnal Ilmiah Hukum.” Legality: Jurnal Ilmiah Hukum, 2020. https://doi.org/10.22219/Ijih.v2i1.11786.

Kotimah, Erwin Kusnul, and Lukman Santoso. "Urgensi Tanda Tangan Dan

Materai Dalam Memberikan Kepastian Hukum Terhadap Kontrak

Waralaba (Franchise) The Urgency of Signatures and Stamps on Giving for Legal Certainty toward Franchise Contracts." Holrev 1, no. 1 (2017): 43-63. http://ojs.uho.ac.id/index.php/holrev/.

Lestari, Tri Wahyu Surya, and Lukman Santoso. "Komparasi Syarat Keabsahan 'Sebab Yang Halal' Dalam Perjanjian Konvensional Dan Perjanjian Syariah." YUDISIA : Jurnal Pemikiran Hukum Dan Hukum Islam 8, no. 2 (April 8, 2018): 281-98. https://doi.org/10.21043/YUDISIA.V8I2.3240.

Prasetyo, Hoedi, and Wahyudi Sutopo. "Industri 4.0: Telaah Klasifikasi Aspek Dan Arah Perkembangan Riset." Jurnal Teknik Industri 13, no. 1 (2018): 17-26.

Purnomosidi, Arie, and Ratna Riyanti. "Perlindungan Bagi Pekerja Di Era 
Revolusi Industri 4.0 Dalam Perspektif Hubungan Industrial Pancasila." In Prosiding Seminar Nasional Hukum Transendental, 4756. Semarang: Universitas Muhammadiyah Surakarta, 2019.

Rahman, Fathur. "Kajian Teoritis Penerapan Dan Perlindungan Hukum Terhadap Pekerja Dalam Perjanjian Kerja Waktu Tertentu (Pkwt) Menurut Undang-Undang Nomor 13 Tahun 2003 Tentang Ketenagakerjaan (Studi Pada PT. Duta Nichirindo Pratama Kota Tangerang).” Jurnal Surya Kencana Dua: Dinamika Masalah Hukum Dan Keadilan 4, no. 1 (December 2017): 87-106.

Sari, Sriti Mayang. "Implementasi Konsep Geo-Office." Pengaruh Teknologi Informasi Pada Impelentasi Konsep Geo-Office, 2006, 2530.

Shalihah, Fithriatus. "Perjanjian Kerja Waktu Tertentu (Pkwt) Dalam Hubungan Kerja Menurut Hukum Ketenagakerjaan Indonesia Dalam Perspektif Ham." Uir Law Review 1, no. 2 (2017): 149-60. https://doi.org/10.25299/uirlrev.2017.1.02.955.

Sunarno. "Beberapa Masalah Pada Perjanjian Kerja Waktu Tertentu Dan Solusinya." Wacana Hukum 3, no. 2 (2009): 19-32. http://ejurnal.unisri.ac.id/index.php/Wacana/article/viewFile/310/272.

Yuli, Yuliana, Sulastri, and Dwi Aryanti. "Implementasi Undang-Undang Ketenagakerjaan Dalam Perjanjian Kerja Antara Perusahaan Dan Tenagakerja Di Perseroan Terbatas." Jurnal Yuridis 5, no. 2 (2018): 186-209. https://doi.org/10.1111/an.1994.35.9.30.3.

\section{Internet}

(PrivyID), PT Privy Identitas Digital. "Ulasan Lengkap: Cara Mengidentifikasi Tanda Tangan Elektronik Palsu." https://www.hukumonline.com/, 2020. https://www.hukumonline.com/klinik/detail/ulasan/lt5d689c0cc9d81/c ara-mengidentifikasi-tanda-tangan-elektronik-palsu.

Burgess, Matt. "What Is the Internet of Things? WIRED Explains." WIRED Explains, 2018. https://www.wired.co.uk/article/internet-of-thingswhat-is-explained-iot.

CNBC Indonesia. "Cerita PNS Yang Mulai 2020 Bisa Ngantor Dari Rumah." $\quad$ www.cnbcindonesia.com, 2019. https://www.cnbcindonesia.com/news/20191124130238-4117540/cerita-pns-yang-mulai-2020-bisa-ngantor-dari-rumah.

Kabar Banten. "Masalah Ketenagakerjaan Selama 2019, Kasus PKWT Mendominasi." www.kabar-banten.com, 2020. https://www.kabarbanten.com/masalah-ketenagakerjaan-selama-2019-kasus-pkwtmendominasi/. 
Kementerian Perindustrian Indonesia. "Industry 4.0 Tingkatkan Produktivitas, Tenaga Kerja, Dan Pasar." www.kemenperin.go.id, 2017. https://www.kemenperin.go.id/artikel/17503/Industry-4.0Tingkatkan-Produktivitas,-Tenaga-Kerja,-dan-Pasar.

_. "Making Indonesia 4.0: Strategi RI Masuki Revolusi Industri Ke4." " www.kemenperin.go.id, 2018. https://www.kemenperin.go.id/artikel/18967/Making-Indonesia-4.0:Strategi-RI-Masuki-Revolusi-Industri-Ke-4.

Mungkasa, Oswar. "Bekerja Jarak Jauh (Telecommuting): Konsep, Penerapan Dan Pembelajaran." 1. Jakarta, 2020. http://workingpapers.bappenas.go.id/index.php/bwp/article/download/5 $2 / 43 /$.

\section{Skripsi}

Pamady, Rahmat Hisyam, and S.H., LL.M Nabiyla Risfa Izzati. "Tinjauan Yuridis Hubungan Hukum Antara Freelancer Dengan Para Pihak Dalam Situs Web Pasar Kerja Online (Studi Kasus Pada Situs Web Sribulancer.Com)." Skripsi Strata 1 Hukum Universitas Gadjah Mada, 2019, viii.

\section{Peraturan Perundang-undangan}

Indonesia, Republik. Undang-Undang Nomor 11 Tahun 2020 tentang Cipta Kerja (2020).

Keputusan Menteri Tenaga Kerja Dan Transmigrasi Republik Indonesia Nomor KEP.100/MEN/VI/2004 Tentang Ketentuan Pelaksanaan Perjanjian Kerja Waktu Tertentu (2004).

Republik Indonesia. Undang-Undang Nomor 13 Tahun 2013 tentang Ketenagakerjaan (2013).

- Undang-Undang Nomor 19 tahun 2016 tentang Perubahan Atas Undang-Undang Nomor 11 Tahun 2008 tentang Informasi dan Transaksi Elektronik (2016). 